\title{
BIOMASSA DAN HASIL LIMA GENOTIPE SORGUM (Sorghum bicolor [L.] Moench) DI LAHAN KERING TANJUNG BINTANG LAMPUNG SELATAN
}

\section{BIOMASS AND YIELD OF FIVE GENOTYPES SORGHUM (Sorghum bicolor [L.] Moench) IN DRY LAND TANJUNG BINTANG SOUTH LAMPUNG}

\author{
Devy Nouva Ristiani ${ }^{1}$, M. Syamsoel Hadi ${ }^{2}$, Kukuh Setiawan ${ }^{3}$, Eko Pramono ${ }^{4}$ \\ ${ }^{1}$ Mahasiswa Program Studi Agroteknologi, Fakultas Pertanian, Universitas Lampung \\ E-mail: devyristiani@yahoo.com
}

Dikirim 10 Februari 2021, Direvisi 12 Maret 2021, Disetujui 29 Maret 2021

\begin{abstract}
Abstrak: Penelitian ini bertujuan untuk mengevaluasi pengaruh lima genotipe yang berbeda terhadap biomassa dan hasil sorgum, menghitung korelasi antara variabel biomassa dan hasil yang diamati, dan menentukan koefisien pengaruh langsung dan koefisien pengaruh tidak langsung antara biomassa terhadap hasil sorgum yang dihitung menggunakan analisis lintas. Penelitian ini dilakukan di lahan yang berada di Desa Sukanegara, Kecamatan Tanjung Bintang, Kabupaten Lampung Selatan, Provinsi Lampung dari bulan April 2019 sampai dengan November 2019. Penelitian ini menggunakan perlakuan tunggal berupa genotipe sorgum yang disusun menggunakan Rancangan Acak Kelompok Lengkap (RAKL) dengan tiga ulangan. Genotipe sorgum yang digunakan dalam penelitian ini antara lain GHP-1, GHP-5, GHP-11, Pahat, dan Numbu. Jumlah seluruh satuan percobaan adalah 15. Pada setiap satu satuan percobaan diambil lima tanaman yang akan digunakan sebagai sampel pengamatan. Hasil penelitian menunjukkan bahwa genotipe GHP-5 (135,2 g) dan Pahat (123,4 g), memiliki bobot biomassa total bagian atas lebih tinggi dibandingkan genotipe GHP-1 (98,0 g) dan Numbu (94,7 g). Kemudian, genotipe Pahat memiliki panjang malai $(26,2 \mathrm{~cm})$, jumlah cabang malai $(42,4$ buah), dan bobot dompolan (head) berbiji (65,1 g) yang lebih tinggi dibandingkan dengan genotipe lainnya. Variabel bobot biji per tanaman yang tinggi ditunjukkan oleh genotipe GHP-5 (37,6 g), Numbu (31,0 g), dan GHP-11(29,6 g). Hasil korelasi menunjukkan bahwa terdapat korelasi positif antara bobot biomassa total bagian atas dan bobot biji per tanaman $\left(\mathrm{r}=0,36^{* *}\right)$. Berdasarkan analisis lintas, terdapat koefisien pengaruh langsung antara bobot biomassa total bagian atas terhadap bobot biji per tanaman $(0,035)$. Kemudian, koefisien pengaruh langsung antara jumlah biji per tanaman terhadap bobot biji per tanaman $(0,995)$ dan bobot 1000 butir terhadap bobot biji per tanaman $(0,346)$. Hal ini menunjukkan bahwa jumlah biji per tanaman dan bobot 1000 butir dalam penelitian ini direkomendasikan sebagai indikator seleksi untuk hasil tinggi pada tanaman sorgum.
\end{abstract}

Kata kunci: biomassa, genotipe, hasil, dan tanaman sorgum

\begin{abstract}
This experiment aims to evaluate the effect of five genotypes on the biomass and yield of sorghum, to calculate correlation between biomass variables and yield components, and to calculate the coefficient of direct effect and indirect effect of biomass component on yield of grain sorghum by using path analysis. This study was conducted in Sukanegara Village, Tanjung Bintang District, South Lampung Regency, Lampung Province from April 2019 to November 2019. This study used single treatment of sorghum genotypes in Completely Randomized Block Design (CRBD) with three replications. The sorghum genotypes used that this study were (GHP-1, GHP5, GHP-11, Pahat, and Numbu). The total number of study units was 15. In each unit of study, five plants were taken as samples of observations. The results showed that genotypes GHP-5 (135,2 g) and Pahat (123,4 g) had a higher above-ground biomass weight than genotypes GHP-1 (98,0 g) and Numbu

$(94,7 \mathrm{~g})$. Then the genotype of Pahat had panicle length $(26,2 \mathrm{~cm})$, number of panicle branches $(42,4$ item), and head weight $(65,1 \mathrm{~g})$ were higher than other genotypes. Then the high grain weight was achieved by the genotype GHP-5 (37,6 g), Numbu (31,0 g), and GHP-11 (29,6 g). This experiment showed that there was a significant correlation between above-ground biomass weight and grain weight per plant $\left(r=0,36^{* *}\right)$. Based on path analysis there was a dirrect effect of above-ground biomass weight on grain weight per plant $(0,035)$. Than, direct effect between number of grain per plant and grain weight per plant $(0,995)$ and 1000 grain weight and grain weight per plant $(0,346)$. It means that number of grain per plant and 1000 grain weight is recommended to be used as selection for high yield.
\end{abstract}

Keywords: biomass, genotypes, yield, and sorghum plants 


\section{PENDAHULUAN}

Sorgum (Sorghum bicolor [L.] Moench) merupakan tanaman serealia yang mempunyai potensi besar untuk dikembangkan di Indonesia karena termasuk tanaman pangan lahan kering yang memiliki adaptasi luas. Tanaman ini toleran terhadap kekeringan dan genangan air dan dapat berproduksi pada lahan kering marjinal. Menurut Pabendon et al. (2012), tanaman sorgum masih mampu tumbuh dengan baik pada musim kering yang panjang ketika tanaman pangan lain tidak dapat tumbuh atau berproduksi. Sehingga sorgum memiliki tempat dalam pola tanam setahun tanpa menggeser kedudukan pangan utama, mengingat tanaman sorgum mempunyai manfaat selain sebagai bahan pangan, yaitu untuk pakan ternak dan bahan baku industri.

Berdasarkan data Kementerian Pertanian (2018), Indonesia masih memiliki lahan kering yang sementara belum diusahakan sebesar 10.770 .888 ha, sedangkan lahan kering yang sementara belum diusahakan di Provinsi Lampung sebesar 41.148 ha. Adanya total luasan lahan kering yang sementara belum diusahakan ini diharapkan dapat dimanfaatkan untuk budidaya tanaman sorgum tanpa menggeser kedudukan tanaman pangan lain yang sudah biasa diusahakan.

Pengembangan sorgum di Indonesia masih perlu mendapat perhatian. Menurut Sirappa (2003), pengembangan sorgum di Indonesia masih tergolong rendah disebabkan oleh minimnya teknologi yang digunakan untuk pengolahan hasil sorgum, tidak adanya jaminan produksi di pasaran dan permintaan yang masih rendah. Petani di Indonesia enggan untuk menanam sorgum, karena tidak memberikan pendapatan yang baik secara ekonomi. Ketersediaan teknologi sangat diperlukan meliputi teknologi budidaya dan pascapanen dalam pengembangan sorgum di Indonesia, serta adanya kebijakan dari pemerintah untuk menjamin harga pasar produksi sorgum.

Biomassa tanaman merupakan gambaran dari proses fotosintesis yang kemudian menghasilkan fotosintat (Gardner et al., 1991). Menurut Michael (1994) menyatakan bahwa biomassa adalah jumlah total bobot kering semua bagian tanaman hidup yang dapat diperoleh dari organ tanaman bagian atas tanah seperti batang, daun, dompolan (head) tanpa biji, dan biji dan dari bagian bawah tanah seperti akar. Dalam penelitian ini, variabel biomassa yang digunakan adalah batang, daun, dan dompolan (head) tanpa biji. Produksi biomassa mengakibatkan pertambahan bobot yang dapat diikuti dengan pertambahan ukuran lain yang dapat dinyatakan secara kuantitatif. Menurut Sungkono (2010), bobot biomassa yang tinggi ditunjukkan oleh tanaman yang mampu mengakumulasikan fotosintat dengan cepat. Pada tanaman sorgum, proses translokasi dan pemanfaatan fotosintat sangat penting untuk mengetahui pendistribusian fotosintat yang berasal dari daun ke organ lain seperti akar, batang, dompolan (head) tanpa biji, dan biji.

Pengukuran distribusi biomassa digunakan untuk mengetahui pembagian fotosintat dari sumber (source) ke target (sink) (Yuliasari et al., 2014). Kemampuan source untuk memproduksi fotosintat dan kemampuan sink untuk menampung fotosintat dapat menentukan produksi dari suatu tanaman. Dalam hal ini, daun dan jaringan tanaman yang berfotosintesis, serta jaringan tanaman yang menjadi tempat akumulasi sementara bahan kering untuk selanjutnya ditranslokasikan ke bagian yang memanfaatkan bahan kering tersebut juga termasuk source (Snyder dan Carlson, 1983). Distribusi fotosintat yang tinggi ke bagian yang bernilai ekonomis (biji) memberikan peluang untuk 
memperoleh hasil yang tinggi juga (Sungkono, 2010).

Pada fase pengisian biji tanaman sorgum, kebutuhan fotosintat dapat diperoleh dari hasil distribusi fotosintat yang sebelumnya tersimpan dalam batang, daun, dan dompolan (head) tanpa biji. Menurut Tabri dan Zubachtirodin (2016), fotosintat yang tersimpan dalam batang, daun, dan dompolan (head) tanpa biji didistribusikan ke biji saat periode pengisian biji. Salah satu faktor yang dapat mengendalikan pendistribusian fotosintat dari hasil fotosintetis yaitu kemampuan genetik dari tanaman itu sendiri.

Perbedaan genotipe tanaman sorgum akan menghasilkan pertumbuhan dan hasil yang berbeda-beda. Hal ini terjadi akibat faktor genetik dan faktor lingkungan tumbuh dari tanaman tersebut. Faktor genetik merupakan salah satu faktor penentu pertumbuhan dan hasil tanaman sorgum. Namun, genetik tanaman juga dapat dipengaruhi oleh lingkungan tumbuhnya (Suryana, 2017). Genetik berkaitan dengan genotipe sorgum, dimana setiap genotipe memiliki sifat dan kemampuan genetik yang berbeda satu sama lainnya dan berpengaruh terhadap hasil tanaman sorgum (Paramita, 2018). Adanya perbedaan genotipe tersebut dapat mempengaruhi pertumbuhan dan hasil sorgum dengan perlakuan yang sama, karena gen berfungsi dalam metabolisme tanaman.

Hubungan antara biomassa dengan hasil sorgum biji dapat diketahui dengan mengacu pada distribusi dan pemanfaatan fotosintat yang dihasilkan oleh daun yang berperan sebagai source untuk selanjutnya didistribusikan ke bagian batang dengan cara melihat besaran korelasinya. Berdasarkan penelitian Dhutmal et al. (2014) menunjukkan bahwa terdapat korelasi positif antara bobot biomassa total bagian atas dan bobot biji per tanaman $(\mathrm{r}=0,64 * *)$. Korelasi positif menunjukkan bahwa peningkatan karakter pertama akan diikuti oleh meningkatnya karakter kedua. Hal ini berarti bahwa peningkatan bobot biomassa total bagian atas akan diikuti oleh peningkatan bobot biji per tanaman pada tanaman sorgum.

Besarnya nilai korelasi yang diperoleh di atas tidak dapat menentukan apakah karakter bobot biomassa total bagian atas dengan nilai korelasi positif tersebut memiliki pengaruh langsung atau tidak langsung dalam meningkatkan hasil sorgum biji, sehingga perlu dilakukan perhitungan analisis lintas (path analysis) yang digunakan untuk mengidentifikasi besarnya koefisien pengaruh langsung maupun koefisien pengaruh tidak langsung antara karakter biomassa terhadap hasil tanaman sorgum.

Selama ini, seleksi untuk genotipe unggul hanya berdasarkan komponen pertumbuhan saja, seperti tinggi tanaman, jumlah daun, diameter batang, dan lainnya. Oleh karena itu, penelitian ini dilakukan untuk mengetahui apakah biomassa juga dapat digunakan sebagai indikator seleksi varietas unggul. Dimana diketahui bahwa dengan adanya pengamatan tentang biomassa pada tanaman sorgum, kita dapat mengetahui distribusi fotosintat ke bagian biji saat fase pengisian biji yang sebelumnya fotosintat tersebut tersimpan dalam batang, daun, dan dompolan (head) tanpa biji. Semakin tinggi fotosintat yang didistribusikan ke bagian biji, maka bobot biji yang diperoleh juga akan semakin meningkat.

Berdasarkan latar belakang tersebut, perlu dilakukan penelitian ini untuk mengetahui perbedaan biomassa dan hasil pada beberapa genotipe tanaman sorgum yang berbeda.

\section{METODOLOGI}

Penelitian ini dilakukan pada bulan April sampai dengan September 2019 pada 
lahan yang terletak di Desa Sukanegara, Kecamatan Tanjung Bintang, Kabupaten Lampung Selatan, Provinsi Lampung dengan kondisi tanah berdasarkan hasil analisis yaitu memiliki $\mathrm{pH}$ sebesar 6,80 dan kandungan lainnya seperti $\mathrm{N}$-total sebesar $0,06 \%$, P-tersedia 14,42 ppm, K-dd 0,15 me/100 g, pasir 36,25\%, debu 36,83\%, dan liat 26,92 \%, sehingga berdasarkan segitiga tekstur tanah tersebut tergolong tanah lempung berliat.

Bahan pada penelitian ini adalah dua genotipe sorgum yang sudah dirilis oleh pemerintah yaitu Pahat dan Numbu dan tiga genotipe sorgum yang belum dirilis oleh pemerintah yaitu GHP (Galur Harapan Pangan) yang terdiri dari GHP-1, GHP-5, dan GHP-11. Pupuk yang digunakan yaitu pupuk Urea, TSP, dan $\mathrm{KCl}$.

Alat yang digunakan dalam penelitian ini berupa alat pengolah tanah (bajak singkal dan bajak rotari), tali plastik, meteran, plang nama genotipe, bambu, label sampel, golok, gunting, cutter, ember, paranet, streples, timbangan elektrik, kertas koran, oven, seed blower, seed counter, alat tulis, dan kamera.

Penelitian ini menggunakan perlakuan tunggal berupa genotipe sorgum yang disusun menggunakan Rancangan Acak Kelompok Lengkap (RAKL) dengan tiga ulangan. Genotipe sorgum yang digunakan dalam penelitian ini antara lain GHP-1, GHP-5, GHP-11, Pahat, dan Numbu. Jumlah seluruh satuan percobaan adalah 15. Pada setiap satu satuan percobaan diambil lima tanaman yang akan digunakan sebagai sampel pengamatan.

Homogenitas ragam diuji dengan uji Levene dan aditivitas data diuji dengan uji Tukey. Jika kedua asumsi terpenuhi, maka dilakukan analisis ragam yang dilanjutkan dengan uji BNT (beda nyata terkecil) pada taraf 5\% dengan menggunakan program Minitab (Versi 17). Untuk mengetahui hubungan antara dua karakter digunakan analisis korelasi dan dilanjutkan dengan analisis lintas. untuk mengetahui pengaruh langsung dan tidak langsung antara variabel $\mathrm{X}$ dengan variabel $\mathrm{Y}$.

\section{Analisis Korelasi}

Nilai korelasi pearson dapat dihitung menggunakan rumus:

$$
\mathrm{r}=\frac{\mathrm{n} \sum \mathrm{xy}-\left(\sum \mathrm{x}\right)\left(\sum \mathrm{y}\right)}{\sqrt{ }\left\{\mathrm{n} \sum \mathrm{x}^{2}-\left(\sum \mathrm{x}\right)^{2}\right\}\left\{\mathrm{n} \sum \mathrm{y}^{2}-\left(\sum \mathrm{y}\right)^{2}\right\}}
$$

Dimana:

n : banyaknya pasangan data $\mathrm{X}$ dan $\mathrm{Y}$

$\sum \mathrm{Xy}:$ hasil perkalian dari total jumlah variabel $\mathrm{X}$ dan variabel $\mathrm{Y}$

$\sum \mathrm{X}$ : total jumlah dari variabel $\mathrm{X}$

$\sum \mathrm{y}$ : total jumlah dari variabel $\mathrm{Y}$

$\sum \mathrm{x}^{2}$ : kuadrat dari total jumlah variabel $\mathrm{X}$

$\sum y^{2}:$ kuadrat dari total jumlah variabel Y

\section{Analisis Lintas}

Data yang telah dianalisis dengan menggunakan analisis korelasi pearson dilanjutkan dengan analisis lintas. Menurut Singh dan Chaudhary (1979), perhitungan analisis lintas (path analysis) dapat dilakukan dengan cara:

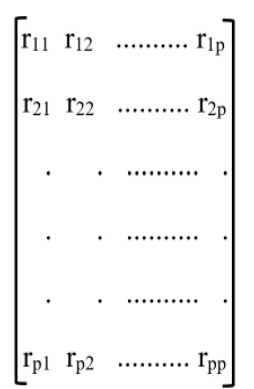

$\mathrm{R}_{\mathrm{x}}$

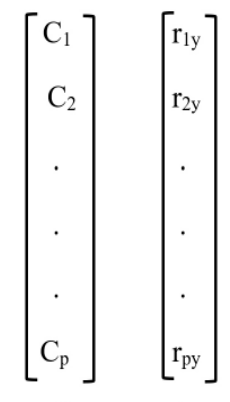

$\underline{\mathrm{C}}$
$\mathrm{R}_{\mathrm{y}}$
Nilai $\mathrm{Ci}$ (pengaruh langsung) dapat dihitung menggunakan rumus sebagai berikut:

$$
C i=R x-1 R y
$$

Dimana :

Rx : Matriks korelasi antarvariabel 
bebas dalam model regresi berganda yang memiliki $\mathrm{p}$ buah variabel bebas, jadi merupakan matriks dengan elemen $\mathrm{rXiXj}$ $(\mathrm{i}, \mathrm{j}=1,2, \ldots, \mathrm{p})$.

$\mathrm{Ci}$ : Vektor koefisien lintasan yang menunjukkan pengaruh langsung setiap peubah bebas yang telah dibakukan terhadap peubah tak bebas.

Ry : Vektor koefisien korelasi antara variabel bebas Xi dimana i $=1,2, \ldots, \mathrm{p}$; dan variabel tak bebas Y.

Pengaruh langsung dari peubah ke-1 terhadap faktor Y diperoleh dari :

Dimana :

$$
\mathrm{P}=\mathrm{RX}-1 \mathrm{~A}
$$

P : Vektor koefesien jalur antara peubah dan faktor hasil (Y).

R-1 : Invers matriks RX

A : Korelasi antara peubah dan faktor hasil

Pengaruh tidak langsung suatu peubah xi melalui peubah ke xj terhadap vektor $Y$ diperoleh dengan rumus :

Dimana :

$$
P i j=r i j ~ P j
$$

rij : Korelasi antara komponen ke-i dengan komponen ke-j

Pij : Pengaruh tidak langsung suatu peubah Xi melalui peubah ke Xj terhadap vektor $\mathrm{Y}$

$\mathrm{Pj} \quad$ : Koefesien jalur komponen ke $\mathrm{j}$ terhadap hasil.

Variabel yang diamati dalam penelitian ini meliputi komponen biomassa (bobot kering batang, bobot kering daun, bobot dompolan (head) tanpa biji, dan bobot biomassa total bagian atas) dan komponen hasil (panjang malai, jumlah cabang malai, bobot dompolan (head) berbiji, jumlah biji per tanaman, bobot biji per tanaman, dan bobot 1000 butir).

\section{HASIL DAN PEMBAHASAN}

Hasil penelitian menunjukkan bahwa terdapat variasi nyata antargenotipe untuk semua variabel pengamatan pada rekapitulasi komponen biomassa dan komponen hasil (Tabel 1). Genotipe memiliki variasi nyata terhadap bobot kering batang, bobot kering daun, bobot dompolan (head) tanpa biji, bobot biomassa total bagian atas, panjang malai, jumlah cabang malai, bobot dompolan (head) berbiji, jumlah biji per tanaman, bobot biji per tanaman, dan bobot 1000 butir. Hasil analisis ragam menunjukkan adanya variasi nyata pada semua variabel, dimana semua variabel ini dapat dilanjutkan untuk analisis selanjutnya, yaitu analisis korelasi dan analisis lintas.

Koefisien keragaman (KK) pada penelitian ini berkisar antara 1,96\%$42,16 \%$

(Tabel 1). Nilai koefisien keragaman yang tinggi ditunjukkan oleh bobot biji per tanaman $(42,16 \%)$, diikuti oleh jumlah biji per tanaman $(42,02 \%)$, bobot kering daun $(31,77 \%)$, dan bobot dompolan (head) berbiji (30,89\%). Kemudian, nilai koefisien keragaman yang lebih rendah ditunjukkan oleh jumlah cabang malai $(25,92 \%)$, bobot kering batang $(23,86 \%)$, bobot biomassa total bagian atas $(21,28 \%)$, panjang malai $(20,33 \%)$, bobot dompolan (head) tanpa biji $(13,28 \%)$, dan bobot 1000 butir $(1,96 \%)$.

Koefisien keragaman (KK) merupakan gambaran tentang keragaman yang ditentukan oleh rasio antara simpangan baku $\left(S_{\mathrm{x}}\right)$ atau nilai kuadrat tengah galat dengan nilai rataan umum (Paiman, 2015). Semakin rendah nilai kuadrat tengah galat dan semakin tinggi nilai rataan umum yang diperoleh juga akan semakin rendah koefisien keragamannya, begitupula sebaliknya. Nilai koefisien keragaman yang semakin kecil menyebabkan derajat keandalan akan semakin tinggi (Harjosuwono et al., 2011). Nilai koefisien 
keragaman dalam penelitian ini diperoleh bahwa pada bobot biji per tanaman menghasilkan koefisien keragaman sebesar $42,16 \%$ lebih tinggi dibandingkan dengan bobot 1000 butir yang menghasilkan koefisien keragaman sebesar 1,96\%.

Tabel 1. Rekapitulasi hasil analisis ragam untuk komponen biomassa dan komponen hasil pada tanaman sorgum

\begin{tabular}{|c|c|c|c|c|c|}
\hline \multirow{2}{*}{ Variabel Pengamatan } & \multirow[b]{2}{*}{ Rataan } & \multicolumn{3}{|c|}{ Kuadrat Tengah } & \multirow{2}{*}{$\begin{array}{c}\text { Koefisien } \\
\text { Keragaman } \\
(\%)\end{array}$} \\
\hline & & Kelompok & Genotipe & Galat & \\
\hline \multicolumn{6}{|l|}{ Komponen Biomassa } \\
\hline Bobot Kering Batang (g) & 76,41 & 194,80 & $1.624,40$ * * & 332,30 & 23,86 \\
\hline Bobot Kering Daun (g) & 28,88 & 196,60 & 627,43 * *** & 84,18 & 31,77 \\
\hline Bobot Dompolan (Head) Tanpa Biji (g) & 8,13 & 1,92 & 8,27 ** & 1,17 & 13,28 \\
\hline Bobot Biomassa Total Bagian Atas (g) & 113,42 & 563,80 & $4.383,40 *$ & 592,70 & 21,28 \\
\hline \multicolumn{6}{|l|}{ Komponen Hasil } \\
\hline Panjang Malai (cm) & 22,21 & 3,21 & $177,78^{* *}$ & 20,40 & 20,33 \\
\hline Jumlah Cabang Malai (buah) & 35,35 & 113,21 & 340,05 ** & 83,92 & 25,92 \\
\hline Bobot Dompolan (Head) Berbiji (g) & 56,44 & 509,80 & $1.001,40^{*}$ & 304,00 & 30,89 \\
\hline Jumlah Biji Per Tanaman (butir) & $1.253,37$ & $363.737,00$ & $651.424,00 *$ & $277.361,00$ & 42,02 \\
\hline Bobot Biji Per Tanaman (g) & 29,77 & 169,60 & $388,80 *$ & 157,60 & 42,16 \\
\hline Bobot 1000 Butir (g) & 24,07 & 0,05 & 233,34 *** & 0,22 & 1,96 \\
\hline
\end{tabular}

Keterangan : $*$ = Nyata pada taraf $5 \%$

$* *$ = Sangat nyata pada taraf $1 \%$

\section{Komponen Biomassa}

Pengamatan pada bobot kering batang (Tabel 2), menunjukkan bahwa dalam penelitian ini genotipe memiliki pengaruh terhadap bobot kering batang. Hasil uji beda nyata terkecil menunjukkan genotipe yang diamati memiliki bobot kering batang yang sama. GHP-5 merupakan genotipe yang memiliki bobot kering batang yang paling berat sebesar 88,4 g, kemudian diikuti oleh genotipe Pahat sebesar 85,2 g dan GHP-11 sebesar 76,2 g. Besar kecilnya bobot kering batang diduga akibat perbedaan ukuran panjang batang dan diameter batang dari tanaman tersebut. Hal ini didukung oleh penelitian Yanuar (2018), yang menyatakan bahwa tanaman sorgum yang memiliki ukuran bobot kering batang yang tinggi didukung oleh diameter batang dan panjang batang yang tinggi pula.
Hasil analisis ragam menunjukkan bahwa bobot kering daun memiliki perbedaan antargenotipenya (Tabel 2). Kemudian berdasarkan hasil uji beda nyata terkecil memperlihatkan genotipe GHP-5 memiliki bobot kering daun yang lebih berat dibandingkan dengan genotipe lainnya sebesar $37,5 \mathrm{~g}$, sedangkan Numbu merupakan genotipe yang memiliki bobot kering daun yang rendah sebesar 21,0 g. Daun adalah organ utama fotosintesis pada tanaman yang menghasilkan fotosintat, semakin banyak jumlah daun maka fotosintat yang dihasilkan akan semakin banyak pada bagian daun tersebut, sehingga bobot kering daun akan meningkat (House, 1985).

Berdasarkan hasil analisis ragam, menunjukkan bahwa terdapat perbedaan bobot dompolan (head) tanpa biji antargenotipenya (Tabel 2). Bobot dompolan (head) tanpa biji berdasarkan hasil uji beda nyata terkecil memperlihatkan bahwa GHP-1, GHP-11, Pahat, dan Numbu merupakan genotipe dengan bobot dompolan (head) tanpa biji yang sama. Genotipe GHP-5 memiliki bobot dompolan (head) tanpa biji tertinggi sebesar 9,4 g. Adanya perbedaan bobot dompolan (head) tanpa biji diduga dipengaruhi oleh banyak atau sedikitnya fotosintat yang terkandung di dalam malai dari masing-masing genotipe sorgum. Menurut Sungkono (2010), peningkatan bobot dompolan (head) tanpa biji akan diikuti dengan peningkatan bobot biji per tanaman. Hal ini terjadi karena fotosintesis yang berlangsung setiap harinya mendasari pengisian fotosintat ke bagian biji. 
Tabel 2. Perbedaan nilai tengah komponen biomassa pada beberapa genotipe tanaman sorgum

\begin{tabular}{lcccc}
\hline Genotipe & BKB & BKD & BDTB & Bio Total \\
\hline & $\ldots \ldots \ldots \ldots \ldots \ldots \ldots \ldots \ldots \ldots \ldots \ldots \ldots \ldots \ldots \ldots \ldots \ldots \ldots \ldots \ldots \ldots \ldots \ldots \ldots \ldots \ldots \ldots \ldots \ldots \ldots \ldots \ldots$ \\
Pahat & $85,2 \mathrm{a}$ & $30,5 \mathrm{bc}$ & $7,7 \mathrm{~b}$ & $123,4 \mathrm{~b}$ \\
GHP.5 & $88,4 \mathrm{a}$ & $37,5 \mathrm{a}$ & $9,4 \mathrm{a}$ & $135,2 \mathrm{a}$ \\
GHP-1 & $66,1 \mathrm{~b}$ & $24,0 \mathrm{~cd}$ & $7,9 \mathrm{~b}$ & $98,0 \mathrm{c}$ \\
Numbu & $66,1 \mathrm{~b}$ & $21,0 \mathrm{~d}$ & $7,5 \mathrm{~b}$ & $94,7 \mathrm{c}$ \\
GHP-11 & $76,2 \mathrm{ab}$ & $31,4 \mathrm{ab}$ & $8,2 \mathrm{~b}$ & $115,8 \mathrm{~b}$ \\
\hline BNT 5\% & 13,3 & 6,7 & 0,8 & 17,7 \\
\hline
\end{tabular}

Keterangan : Angka yang diikuti huruf yang sama pada kolom yang menunjukkan tidak berbeda nyata berdasarkan uji BNT 5\%. BKB : Bobot Kering Batang, BKD : Bobot Kering Daun, BDTB : Bobot Dompolan (head) tanpa Biji, Bio Total : Bobot Biomassa Total Bagian Atas.

Pengamatan bobot biomassa total bagian atas memiliki perbedaan antargenotipe pada hasil analisis ragamnya (Tabel 2). Pengamatan bobot biomassa total bagian atas memiliki perbedaan antargenotipe pada hasil analisis ragamnya. Berdasarkan hasil uji beda nyata terkecil, genotipe GHP-5 dan Pahat memiliki bobot biomassa total bagian atas yang lebih berat berturut-turut sebesar 135,2 g dan 123,4 g. Kemudian, genotipe GHP-1 dan Numbu memiliki bobot biomassa total bagian atas yang sama rendah. Bobot biomassa total bagian atas diperoleh dari penggabungan bobot kering batang, bobot kering daun, dan bobot dpmpolan (head) tanpa biji. Perbedaan biomassa secara umum dipengaruhi oleh besarnya produk fotosintesis yang dihasilkan dan berakibat pada peningkatan bobot kering tanaman. Bobot kering yang tinggi dipengaruhi oleh banyaknya penimbunan hasil fotosintesis.

\section{Komponen Hasil}

Perbedaan antargenotipe ditunjukkan untuk semua variabel pengamatan pada komponen hasil (Tabel 3). Panjang malai memiliki perbedaan antargenotipe berdasarkan hasil analisis ragamnya. Hasil uji beda nyata terkecil memperlihatkan bahwa Pahat, GHP-5, dan GHP-11 merupakan genotipe dengan panjang malai yang sama. Panjang malai adalah komponen penting pada tanaman sorgum yang menghasilkan biji karena merupakan tempat malai tumbuh dan malai merupakan ruang tempat biji sorgum tumbuh dan berkembang. Tanaman sorgum yang memiliki genotipe berbeda akan memiliki tampilan tanaman yang bervariasi akibat adanya susunan gen yang berbeda dalam setiap benih sorgum. Menurut Suryana (2017), adanya perbedaan genotipe tersebut akan mempengaruhi pertumbuhan dan perkembangan tanaman termasuk ukuran panjang malai.

Hasil analisis ragam menunjukkan bahwa jumlah cabang malai pada penelitian ini memiliki perbedaan antargenotipenya (Tabel 3). Berdasarkan hasil uji beda nyata terkecil memperlihatkan bahwa genotipe GHP-1 dan GHP-5 memiliki jumlah cabang malai yang sama. Jumlah cabang malai terbanyak ditunjukkan oleh genotipe Pahat sebesar 42,4 buah. Malai merupakan tempat tumbuh dan menempelnya biji sorgum. Semakin banyak malai yang dihasilkan, maka akan diikuti dengan banyaknya jumlah biji tanaman sorgum.

Bobot dompolan (head) berbiji pada hasil analisis ragam dalam penelitian ini menunjukkan berbeda nyata antargenotipenya. Berdasarkan hasil uji beda nyata terkecil, genotipe Pahat memiliki bobot dompolan (head) berbiji yang lebih berat dibandingkan dengan genotipe lainnya sebesar $65,1 \mathrm{~g}$. GHP-11 dan GHP-5 merupakan genotipe yang memiliki bobot dompolan (head) berbiji yang sama, sedangkan GHP-1 merupakan genotipe yang memiliki bobot dompolan 
(head) berbiji yang rendah sebesar 45,0 g. Bobot dompolan (head) terdiri dari malai dengan biji yang menempel pada malai tersebut. Besar kecilnya bobot dompolan (head) diduga dipengaruhi oleh bobot dompolan (head) dan bobot biji per tanaman dari masing-masing genotipe.

Tabel 3. Perbedaan nilai tengah komponen hasil pada beberapa genotipe tanaman sorgum

\begin{tabular}{|c|c|c|c|c|c|c|}
\hline Cenotipe & PM & JCM & $\mathrm{BO} . \mathrm{H}$ & JBPT & BBPT & B1000 \\
\hline & ....m.... & ...buahh... & & 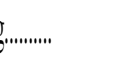 & ...butiti... & \\
\hline Pahat & $26,2 \mathrm{a}$ & 42,4 a & $65,1 \mathrm{a}$ & $1.267,8 \mathrm{abc}$ & 24,26 & \\
\hline GHP.5 & $23,2 \mathrm{a}$ & 35,7 be & 59,5 ab & $1,502,5 \mathrm{a}$ & $37,6 \mathrm{a}$ & \\
\hline GHP.I & $19,3 \mathrm{~b}$ & $32,7 \mathrm{bc}$ & $45,0 \mathrm{c}$ & $1,021,6 \mathrm{c}$ & 26,60 & 160 \\
\hline Numbu & $18,0 \mathrm{~b}$ & $29,6 \mathrm{c}$ & $51,2 b c$ & $1.068,3 b c$ & $31,0 a b$ & \\
\hline GHP-11 & 24,3 a & 30,3 ab & 61,5 ab & $1.406,7 \mathrm{ab}$ & $29,6 \mathrm{ab}$ & \\
\hline BNT5\% & 3,3 & 6,7 & 12,7 & 383,7 & 9,1 & \\
\hline
\end{tabular}

Keterangan : Angka yang diikuti huruf yang sama pada kolom yang sama menunjukkan tidak berbeda nyata berdasarkan uji BNT 5\%. PM : Panjang Malai, JCM : Cabang Malai, BO.H: Bobot Dompolan (head) berbiji, JBPT : Jumlah Biji Per Tanaman, BBPT : Bobot Biji Per Tanaman, B1000 : Bobot 1000 Butir.

Hasil analisis ragam memperlihatkan bahwa jumlah biji per tanaman dalam penelitian ini berbeda nyata antargenotipenya (Tabel 3). Hasil analisis ragam memperlihatkan bahwa jumlah biji per tanaman dalam penelitian ini berbeda nyata antargenotipenya. Pada Tabel 3 menunjukkan bahwa genotipe GHP-5, GHP-11, dan Pahat memiliki jumlah biji per tanaman yang sama berdasarkan hasil uji beda nyata terkecil. Kemudian, genotipe GHP-1 memperlihatkan bahwa memiliki jumlah biji per tanaman yang paling rendah (1.021,6 butir). Jumlah biji per tanaman berkaitan dengan ukuran besar atau kecilnya biji yang diperoleh dari suatu tanaman. Menurut penelitian Suryaningsih et al. (2018), menyatakan bahwa apabila tanaman menghasilkan biji yang banyak, maka ukuran biji akan lebih kecil dan sebaliknya apabila jumlah biji per tanaman sedikit maka ukuran biji tersebut besar yang ditunjukan dengan bobot 100 biji.

Bobot biji per tanaman dalam penelitian ini menunjukkan perbedaan antargenotipe berdasarkan hasil analisis ragamnya. Pada Tabel 3 memperlihatkan bahwa genotipe GHP-1 dan Pahat memiliki bobot biji per tanaman yang sama berdasarkan hasil uji beda nyata terkecil berturut-turut sebesar 26,6 g dan $24,2 \mathrm{~g}$. Besar kecilnya bobot biji per tanaman didukung oleh bobot dompolan dan panjang malai atau salah satunya dari masing-masing genotipe tanaman sorgum. Dalam penelitin ini, diperoleh bahwa genotipe GHP-5 memiliki bobot dompolan (head) berbiji yang tinggi dibandingkan dengan genotipe lainnya, dan terbukti bahwa genotipe GHP-5 juga memiliki bobot biji per tanaman yang lebih besar dibandingkan genotipe Pahat dan GHP-1 (37,6 g).

Hasil analisis ragam memperlihatkan bahwa bobot 1000 butir pada penelitian ini memiliki perbedaan antargenotipenya. Genotipe Numbu memiliki bobot 1000 butir paling tinggi berdasarkan hasil uji beda nyata terkecil sebesar 29,0 g. Kemudian, Pahat merupakan genotipe yang memiliki bobot 1000 butir yang terendah sebesar 19,1 g. Adanya perbedaan bobot 1000 butir disebabkan oleh perbedaan ukuran biji yang dihasilkan oleh masingmasing genotipe sorgum. Hal ini didukung oleh Gardner et al. (1991), yang menyatakan bahwa perbedaan genotipe tanaman akan menghasilkan ukuran dan kualitas biji yang berbeda-beda. Genotipe tersebut dipengaruhi oleh gen yang ada pada tanaman tersebut. 


\section{Korelasi}

Komponen biomassa dan komponen hasil pada tanaman sorgum saling berhubungan satu sama lain, untuk mengetahui hubungan tersebut, maka dilakukan analisis korelasi. Analisis korelasi merupakan tingkat keeratan hubungan antara dua variabel yang bersifat bebas, bebas dalam hal ini berarti nilai korelasi tersebut dapat bolak-balik. Ada dua jenis korelasi, yaitu korelasi positif dan korelasi negatif. Apabila nilai koefesien korelasi positif, maka peningkatan komponen pertama akan meningkatkan komponen kedua. Kemudian nilai korelasi negatif, berarti peningkatan komponen pertama akan menurunkan komponen kedua (Davis dan Djamaris, 2018).

Pada penelitian ini variabel utama yang digunakan adalah bobot biji per tanaman. Melalui bobot biji per tanaman yang berat, maka kemampuan tanaman sorgum untuk meningkatkan hasil biji sorgum yang tinggi melalui seleksi dalam pemuliaan tanaman semakin tinggi dan peluang untuk melakukan seleksi pada karakter yang diinginkan semakin mudah.

Variabel yang memiliki korelasi positif terhadap bobot biji per tanaman (Tabel 4), ditunjukkan oleh bobot kering batang dan bobot biji per tanaman yang berkorelasi positif $\left(\mathrm{r}=0,26^{*}\right)$. Besar kecilnya bobot kering batang diduga akibat perbedaan ukuran panjang batang dan diameter batang dari tanaman tersebut. Tanaman sorgum yang memiliki diameter batang yang besar memungkinkan fotosintat yang tersimpan dalam batang juga menjadi lebih banyak dan berpengaruh terhadap pengisian biji (Anas dan Suhanto, 2018).
Tabel 4. Nilai korelasi Pearson antara komponen biomassa dan komponen hasil tanaman sorgum

\begin{tabular}{|c|c|c|c|c|c|c|c|c|c|c|}
\hline & B & BKD & BDTB & Bio Iotal & PM & ICYI & $\mathrm{BO} . \mathrm{H}$ & IBPT & BBPT & $\mathrm{B} 100$ \\
\hline KB & & 0,58 㸁 & 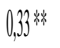 & 0,9 蜶 & $0,35 \%$ & 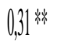 & $0,34 \psi^{2}$ & $0,0,0$ 糛 & 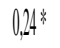 & $-0,29$ \\
\hline SKD & 0,00 & & 0,50 敞 & $0,82{ }^{*}$ & $0,44^{*}$ & $0,40 *$ & $0,0,0$ 粠 & $0,33^{0}$ & $0,46 x^{*}$ & $\cdot 0,30$ \\
\hline $\mathbb{T B}$ & 0,00 & 0,00 & & 0,48 急 & 0,11 & 0,13 & 0,07 & $0.27 \%$ & $(,-2)$ & $0,0,2$ \\
\hline iototal & 0,00 & 0,00 & $0,0,0$ & & $0,42^{*}$ & $0,388^{\circ}$ & $0,43^{4}$ & $0,43^{*}$ & $0,366^{*}$ & 0,32 \\
\hline DIV & 0,00 & 0,00 & 0.34 & 0,00 & & $0,0,00^{4}$ & $0,466^{4}$ & 䍃 & 0.21 & -0.55 \\
\hline M & 0,01 & 0,00 & 0,28 & 0,00 & 0,00 & & $0,0,0$ 綂 & $0,02^{2}$ 粠 & 0,77 䊪 & $-0,43 *$ \\
\hline H & 0,00 & 0,00 & 0,57 & 0,00 & 0,00 & 0,00 & & 0,68 䊉 & 0,40 & 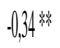 \\
\hline PPT & 0,01 & 0,00 & 0,02 & 0,00 & 0,00 & 0,00 & 0,00 & & $0,9,4$ 粠 & $\cdot 0, \mathbb{2})$ \\
\hline DDDT & 0,04 & 0,00 & 0,02 & 0,00 & 0,08 & 0,00 & 0,00 & 0,00 & & 0,13 \\
\hline 000 & 001 & 0,01 & 0,84 & 0,00 & 0,00 & 0,00 & 0,00 & 0,09 & $0,4 /$ & \\
\hline
\end{tabular}

Keterangan : Nilai yang berada di atas diagonal menunjukkan besarnya nilai korelasi, yang berada di bawah diagonal menunjukkan peluang adanya korelasi, $<0,05$ menunjukkan nyata $(*)$, dan nilai <0,01 menunjukkan sangat nyata $(* *)$. banyaknya data $(\mathrm{n})=75$. BKB : Bobot Kering Batang, BKD : Bobot Kering Daun, BDTB : Bobot Dompolan (Head) tanpa Biji,Bio Total : Bobot Biomassa Total Bagian Atas, PM : Panjang Malai, JCM : Jumlah Cabang Malai, BO.H: Bobot Dompolan (Head) Berbiji, JBPT : Jumlah Biji Per Tanaman, BBPT : Bobot Biji Per Tanaman, B1000 : Bobot 1000 Butir.

Bobot kering daun dan bobot biji per tanaman memiliki korelasi positif $(\mathrm{r}=0,52 * *)$. Perbedaan bobot kering daun disebabkan oleh adanya perbedaan jumlah daun yang dihasilkan. Semakin banyak jumlah daun yang dihasilkan oleh tanaman cenderung semakin besar pula hasil fotosintesis yang didapatkan (Anas dan Suhanto, 2018). Semakin banyak jumlah daun yang terbentuk maka kapasitas 
tanaman dalam melakukan proses fotosintesis akan semakin besar (Putri et al., 2017). Proses fotosintesis inilah yang akan menghasilkan sebagai bobot kering tanaman untuk selanjutnya didistribusikan ke biji.

Selanjutnya, untuk bobot biomassa total bagian atas berkorelasi positif bobot biji per tanaman $(\mathrm{r}=0,52 * *)$. Biomassa merupakan jumlah total bobot kering tanaman yang dapat diperoleh dari bagian atas tanah seperti batang, daun, dan biji dan dari bagian bawah tanah seperti akar (Michael, 1994). Bobot biomassa total bagian atas diperoleh dengan cara menggabungkan bobot yang berasal dari brangkasan kering seperti bobot kering batang dan bobot kering daun.

Produksi biomassa mengakibatkan bertambahnya bobot yang dapat diikuti dengan pertambahan ukuran lain yang dapat dinyatakan secara kuantitatif dalam hal ini bobot biji per tanaman. Menurut Sungkono (2010) menyatakan bahwa besarnya sumbangan bobot dari masingmasing brangkasan kering akan mempengaruhi hasil akhir dari bobot biomassa total bagian atas.

Dalam penelitian ini diperoleh bahwa terdapat korelasi positif antara bobot biomassa total bagian atas dan bobot biji per tanaman pada tanaman sorgum $\left(\mathrm{r}=0,36^{* *}\right)$, yang berarti bahwa peningkatan bobot biomassa total bagian atas akan diikuti dengan meningkatnya bobot biji per tanaman sorgum. Hal ini sejalan dengan penelitian Dhutmal et al. (2014) yang menunjukkan bahwa terdapat korelasi antara bobot biomassa total bagian atas dengan bobot per tanaman pada tanaman sorgum $(\mathrm{r}=0,64 * *)$.

Panjang malai dan jumlah cabang malai memperlihatkan bahwa berkorelasi positif $\left(\mathrm{r}=0,60^{* *}\right)$, yang diikuti korelasi positif antara panjang malai dan bobot dompolan (head) berbiji ( $\left.\mathrm{r}=0,46^{* *}\right)$, serta panjang malai dan jumlah biji per tanaman $\left(\mathrm{r}=0,36^{* *}\right)$. Hal ini disebabkan karena cabang malai dan biji pada sorgum tumbuh pada malai. Malai merupakan tempat tumbuh dan menempelnya biji sorgum.

Rizki dan Damanhuri (2019) menyatakan bahwa di tengah malai terdapat sumbu malai tempat cabang malai menempel, dengan biji yang terletak pada cabang malai tersebut. Panjang malai merupakan komponen yang penting pada sorgum untuk menghasilkan biji karena merupakan tempat malai tumbuh dan malai merupakan ruang tempat biji sorgum tumbuh dan berkembang. Semakin panjang ukuran panjang malai akan diikuti dengan bertambahnya bobot dompolan (head) berbiji dan jumlah biji per tanaman.

Dalam penelitian ini memperlihatkan adanya korelasi positif antara panjang malai dan bobot dompolan (head) berbiji $\left(\mathrm{r}=0,46^{* *}\right)$ dan korelasi positif antara panjang malai dan jumlah biji per tanaman $\left(\mathrm{r}=0,36^{* *}\right)$. Namun, panjang malai dan bobot 1000 butir menunjukkan korelasi negatif $\left(\mathrm{r}=-0,55^{* *}\right)$. Hal ini diduga disebabkan panjang malai yang semakin tinggi hanya mampu meningkatkan jumlah cabang malai, bobot dompolan (head) berbiji, dan jumlah biji per tanaman saja, sehingga bobot 1000 butirnya menurun.

Hasil penelitian Din et al. (2012), menunjukkan bahwa karakter bobot dompolan (head) berbiji dan karakter bobot biji per tanaman berkolerasi positif $\left(\mathrm{r}=0,92^{* *}\right)$. Hal ini mengindikasikan bahwa hasil biji yang tinggi diperoleh dari bobot dompolan (head) berbiji yang lebih besar dan berat. Dalam penelitian ini juga diperoleh bahwa bobot dompolan (head) berbiji dan bobot biji tanaman sorgum berkolerasi positif $(\mathrm{r}=0,58 * *)$. Kemudian Sungkono (2010) dalam penelitiannya menyatakan bahwa peningkatan bobot dompolan (head) tanpa biji akan diikuti 
dengan peningkatan bobot biji per tanaman. Hal ini terjadi karena fotosintesis yang berlangsung setiap harinya mendasari pengisian fotosintat ke bagian biji. Sesuai dengan penelitian ini yang menunjukkan bahwa terdapat korelasi antara bobot dompolan (head) tanpa biji dan bobot biji per tanaman pada tanaman sorgum $(\mathrm{r}=0,28 *)$.

Penelitian ini juga menunjukkan adanya korelasi negatif antara bobot kering batang dan bobot 1000 butir ( $\mathrm{r}=-0,29 * *)$, bobot kering daun dan bobot 1000 butir (r=$0,30 * *)$, bobot biomassa total bagian atas dan bobot 1000 butir ( $\mathrm{r}=-0,32 * *)$, panjang malai dan bobot 1000 butir $\left(\mathrm{r}=-0,55^{* *}\right)$, jumlah cabang malai dan bobot 1000 butir $\left(\mathrm{r}=-0,43^{* *}\right)$, serta bobot dompolan (head) berbiji dan bobot 1000 butir ( $\mathrm{r}=-0,34 * *)$.

Adanya nilai korelasi positif antara komponen biomassa dan komponen hasil, menunjukkan bahwa peningkatan komponen biomassa akan diikuti oleh peningkatan komponen hasil pada tanaman sorgum, kecuali pada bobot 1000 butir yang memiliki korelasi negatif terhadap variabel lainnya. Korelasi negatif menunjukkan bahwa peningkatan komponen pertama akan diikuti dengan menurunnya komponen kedua.

\section{Analisis Lintas}

Pendugaan koefesien korelasi tidak memberikan informasi tentang sumbangan komponen biomassa dan komponen hasil terhadap komponen utama, dalam penelitian ini bobot biji per tanaman adalah komponen utama. Oleh karena itu analisis dianjutkan dengan analisis lintas.

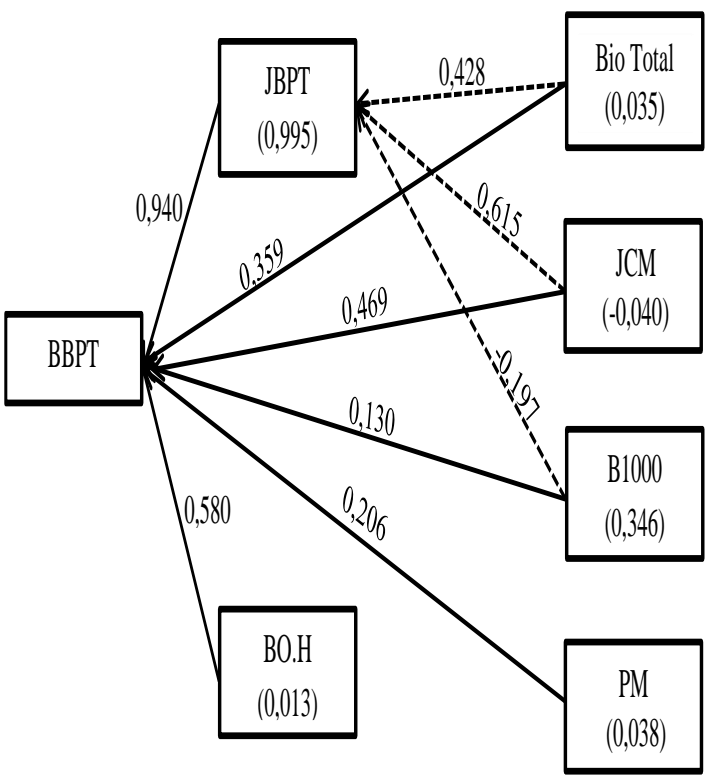

Gambar 1. Koefisien pengaruh langsung dan koefisien pengaruh tidak langsung antara bobot biomassa total terhadap bobot biji per tanaman pada tanaman sorgum.

Keterangan :

*Angka di dalam kotak menunjukkan koefisien pengaruh langsung terhadap bobot biji per tanaman

*Anak panah dengan garis putus-putus menunjukkan koefisien pengaruh tidak langsung terhadap bobot biji per tanaman

*Anak panah dengan garis lurus menunjukkan koefisien pengaruh total terhadap bobot biji per tanaman

BBPT : Bobot Biji Per Tanaman

Bio Total : Bobot Biomassa Total

$$
\text { Bagian Atas }
$$

PM : Panjang Malai

JCM : Jumlah Cabang Malai

BO.H : Bobot Dompolan (head) Berbiji

JBPT : Jumlah Biji Per Tanaman

B1000 : Bobot 1000 Biji

Perhitungan koefisien pengaruh langsung dan koefisien pengaruh tidak langsung antara bobot biomassa total bagian atas dengan bobot biji per tanaman pada tanaman sorgum dihitung menggunakan analisis lintas (path analysis), yang bertujuan untuk memilah koefisien korelasi menjadi pengaruh langsung dan tidak langsung. Bobot biomassa total 
bagian atas yang digunakan merupakan gabungan dari bobot kering batang, bobot kering daun, dan bobot dompolan (head) tanpa biji.

Hasil perhitungan analisis lintas (Gambar 1), menunjukkan bahwa bobot biomassa total bagian atas memiliki koefisien pengaruh langsung terhadap bobot biji per tanaman sebesar 0,035 dan memiliki koefisien pengaruh total terhadap bobot biji per tanaman sebesar 0,359. Namun, bobot biomassa total bagian atas memiliki koefisien pengaruh tidak langsung terhadap bobot biji per tanaman melalui jumlah biji per tanaman sebesar 0,428 . Jika koefisien pengaruh langsung bobot 1000 butir terhadap bobot biji per tanaman sebesar 0,346 dan memiliki pengaruh total sebesar 0,130 . Namun, bobot 1000 butir memiliki koefisien pengaruh tidak langsung terhadap bobot biji per tanaman melalui jumlah biji per tanaman sebesar -0,197.

Jika koefisien pengaruh langsung jumlah biji per tanaman (Gambar 1) terhadap bobot biji per tanaman sorgum sebesar 0,995 dan memiliki koefisien pengaruh total terhadap bobot biji per tanaman sebesar 0,940. Hal ini menunjukkan bahwa jumlah biji per tanaman merupakan karakter yang memiliki koefisien pengaruh langsung paling besar terhadap bobot biji per tanaman yang diikuti oleh koefisien pengaruh langsung bobot 1000 butir. Kemudian, untuk pengaruh langsung dan pengaruh tidak langsung dari variabel yang lainnya disajikan pada Tabel 5.

Tabel 5. Koefisien pengaruh langsung dan koefisien pengaruh tidak langsung antara bobot biomassa total bagian

atas terhadap bobot biji per tanaman pada tanaman sorgum

\begin{tabular}{lcccccc}
\hline Karakter & Bio Total & PM & JCM & B0.H & JBPT & B1000 \\
\hline Bio Total & 0,035 & 0,015 & 0,013 & 0,015 & 0,015 & $-0,011$ \\
PM & 0,016 & 0,038 & 0,023 & 0,017 & 0,014 & $-0,021$ \\
JCM & $-0,015$ & $-0,024$ & $-0,040$ & $-0,024$ & $-0,025$ & 0,017 \\
B0.H & 0,006 & 0,006 & 0,008 & 0,013 & 0,009 & $-0,005$ \\
JBPT & 0,428 & 0,362 & 0,615 & 0,676 & 0,995 & $-0,197$ \\
B1000 & $-0,111$ & $-0,190$ & $-0,149$ & $-0,118$ & $-0,069$ & 0,346 \\
\hline Total & 0,359 & 0,206 & 0,469 & 0,580 & 0,940 & 0,130 \\
\hline Ke
\end{tabular}

Keterangan :

*Angka yang bercetak tebal merupakan nilai pengaruh langsung terhadap bobot biji per tanaman

Bio Total : Bobot Biomassa Total Bagian Atas

PM : Panjang Malai

JCM : Jumlah Cabang Malai

BO.H : Bobot Dompolan (head)

JBPT : Jumlah Biji Per

Tanaman

B1000 : Bobot 1000 Biji

Hasil analisis lintas yang disajikan pada Tabel 5, menunjukkan bahwa karakter bobot biomassa total bagian atas memiliki koefisien pengaruh langsung terhadap bobot biji per tanaman sebesar 0,035. Kemudian, hasil analisis lintas lainnya menunjukkan bahwa jumlah biji per tanaman dan bobot 1000 butir memiliki koefisien pengaruh langsung yang lebih besar terhadap bobot biji per tanaman dibandingkan dengan variabel lainnya berturut-turut sebesar 0,995 dan 0,346. Hal ini disebabkan karena fotosintat yang sebelumnya tersimpan dalam batang, daun, dan dompolan (head) tanpa biji sebagai bobot biomassa total bagian atas akan didistribusikan ke bagian biji saat tanaman memasuki fase pengisian biji (Tohari, 2007) yang selanjutnya berpengaruh terhadap jumlah biji per tanaman dan bobot 1000 butir pada tanaman sorgum. Hal ini sejalan dengan penelitian Ariska et al. (2017) bahwa produksi biomassa dan distribusi fotosintat merupakan penentu dari hasil yang dipanen. Fotosintat yang 
diakumulasikan pada bobot biomassa total bagian atas akan ditranslokasikan ke bagian biji. Sehingga, diperoleh bahwa jumlah biji per tanaman dan bobot 1000 butir memiliki koefisien pengaruh langsung yang lebih besar terhadap bobot biji per tanaman.

Menurut Sinclair dan deWit (1976), juga menyatakan bahwa biji sorgum dapat memperoleh fotosintat saat memasuki fase pengisian biji yang berasal dari hasil distribusi fotosintat yang sebelumnya tersimpan dalam batang, daun, dan dompolan (head) tanpa biji. Dalam penelitian ini, diperoleh bahwa jumlah biji per tanaman memiliki koefisien pengaruh langsung yang paling besar terhadap bobot biji per tanaman pada tanaman sorgum yang diikuti oleh bobot 1000 butir. Semakin banyak fotosintat yang didistribusikan ke bagian biji, maka jumlah biji per tanaman dan bobot 1000 butir akan semakin banyak dan berakibat pada meningkatnya bobot biji per tanaman. Sehingga, karakter jumlah biji per tanaman dan bobot 1000 butir dapat digunakan sebagai salah satu kriteria seleksi tanaman untuk memperoleh genotipe unggul yang memiliki daya hasil tinggi pada tanaman sorgum.

\section{KESIMPULAN}

Berdasarkan hasil penelitian yang telah dilakukan, dapat disimpulkan bahwa:

1. Genotipe GHP-5 (135,2 g) dan Pahat $(123,4 \mathrm{~g})$, memiliki bobot biomassa total bagian atas lebih tinggi dibandingkan genotipe GHP-1 (98,0 g) dan Numbu (94,7 g). Kemudian genotipe Pahat memiliki panjang malai $(26,2 \mathrm{~cm})$, jumlah cabang malai ( 42,4 buah), dan bobot dompolan (head) berbiji $(65,1 \mathrm{~g})$ yang lebih tinggi dibandingkan dengan genotipe lainnya. Bobot biji per tanaman tertinggi ditunjukkan oleh genotipe GHP-5 (37,6 g), Numbu (31,0 g), dan GHP-11 (29,6 g).

2. Hasil korelasi menunjukkan bahwa terdapat korelasi positif antara bobot biomassa total bagian atas dan bobot biji per tanaman $(\mathrm{r}=0,36 * *)$.

3. Terdapat koefisien pengaruh langsung antara bobot biomassa total bagian atas terhadap bobot biji per tanaman $(0,035)$. Kemudian, koefisien pengaruh langsung antara jumlah biji per tanaman terhadap bobot biji per tanaman $(0,995)$ dan bobot 1000 butir terhadap bobot biji per tanaman $(0,346)$. Hal ini menunjukkan bahwa jumlah biji per tanaman dan bobot 1000 butir direkomendasikan sebagai indikator seleksi untuk hasil tinggi pada tanaman sorgum.

\section{DAFTAR PUSTAKA}

Anas dan Suhanto, A. 2018. Keragaan penampilan lima genotipe sorgum manis (Sorghum bicolor (L.) Moench) introduksi Jepang d।Jatinangor Indonesia. Zuriat 29(2) : 80-87.

Andriani, A dan Isnaini, M. 2013. Morfologi dan Fase Pertumbuhan Sorgum. Balai Penelitian Tanaman Serealia. Sulawesi Selatan. $22 \mathrm{hlm}$.

Ariska, T., Sebayang, H.T. dan Suminarti, N.E. 2017. Upaya efisiensi

pemanfaatan lahan melalui penanaman tanaman sela dalam sistem tanam

tumpangsari dengan tanaman sorgum di lahan kering. Jurnal Produksi

Tanaman 5(8): 1367-1374.

Davis, W. dan Djamaris, A.R.A. 2018. Metode Statistik untuk Ilmu dan Teknologi Pangan. UB Press. Jakarta. $154 \mathrm{hlm}$.

Dhutmal, R.R., More, A.W., Kalpande, H.V., Mundhe, A.G., Bakar, S.A., and Aundhekar, R.I. 2014. Correlation and path analysis studies in post rainy sorghum (Sorghum bicolor L.) genotypes. Journal of 
Agroecology and Natural Resource Management 1(4) : 258-262.

Din, A.T., Eatemad, H.M., and Ali, E.A. 2012. Path coefficient and correlation assessment of yield and yield associated traits in sorghum (Sorghum bicolor L.) genotypes. American-Eurasian Jounal Agriculture and Environtment Science 12(6) : 815819 .

Gardner, F.P., Pearce, B., dan Mitchell, R.L. 1991. Fisiologi Tanaman Budidaya. Universitas Indonesia Press. Jakarta. $428 \mathrm{hlm}$.

Harjosuwono, B.A., Arnata, I.W., dan Puspawati, G.A.K.D. 2011. Rancangan Percobaan Teori, Aplikasi SPSS dan Excel. Lintas Kata Publishing. Malang. $77 \mathrm{hlm}$.

House, L.R. 1985. A Guide to Sorghum Breeding 2nd International Crops. Research Institute for Semi-Arid Tropics. India. $206 \mathrm{hlm}$.

Kementerian Pertanian. 2018. Statistik Lahan Pertanian Tahun 2014-2018. Pusat Data dan Sistem Informasi Pertanian. Jakarta. 231 hlm.

Michael, P. 1994. Metode Ekologi untuk Penyelidikan Lapangan dan Laboratorium. UI Press. Jakarta.

Pabendon, M.B., Masud, S., Rosalia, S., Sarungallo, dan Nur, A. 2012. Penampilan fenotipik dan stabilitas sorgum manis untuk bahan baku bioetanol. Jurnal Pertanian Tanaman Panga 31(1) : $10 \mathrm{hlm}$.

Paiman, M.P. 2015. Perancangan Percobaan untuk Pertanian. UPY Press. Yogyakarta. $440 \mathrm{hlm}$.
Paramita, A.I. 2018. Pengaruh beberapa genotipe terhadap pertumbuhan dan hasil sorgum (Sorghum bicolor [L.] Moench). Skripsi. Fakultas Pertanian Universitas Lampung. Bandar Lampung. $88 \mathrm{hlm}$.

Putri, Y.A., Sebayang, H.T., dan Suminarti, N.E. 2017. Pengaruh pengurangan jumlah daun dan posisi daun pada tanaman sorgum. Jurnal Produksi Tanaman 5(10) : 1716-1723.

Rizki, A.N. dan Damanhuri. 2019. Penampilan 12 genotip sorgum (Sorghum bicolor L.) pada musim hujan. Jurnal Produksi Tanaman 7(9) : 1595-1601.

Sinclair, T.R. and deWit, C.R. 1976. Analysis of the carbon and nitrogen limitations to soybean yield. Journal Agronomy. Madison. 8 p.

Singh, R.K. and Chaudhary, B.D. 1979. Biometrical Methods in Quantitative Genetic Analysis. Kalyani Publishers. Ludhiana New Delhi. 302 p.

Sirappa, M.P. 2003. Prospek pengembangan sorgum di indonesia sebagai komoditas alternatif untuk pangan, pakan, dan industri. Jurnal Litbang Pertanian 22(4) : $8 \mathrm{hlm}$.

Snyder, F.W. and Carlson, G.E. 1983. Selecting for partitioning of photosynthetic products in crops. Advances in Agronomy 37 : 47-69.

Sungkono. 2010. Seleksi galur mutan sorgum (Sorghum bicolor (L.) Moench) untuk produktivitas biji dan bioetanol tinggi di tanah masam melalui pendekatan parcipatory plant breeding. Disertasi. Sekolah 
Pascasarjana Institut Pertanian Bogor.

Bogor. $184 \mathrm{hlm}$.

Suryana, I.A. 2017. Penampilan agronomis dan hasil nira beberapa genotipe sorgum (Sorghum bicolor [L.] Moench) yang ditanam secara tumpangsari dengan ubikayu (Manihot esculenta Crantz) pada dua lokasi berbeda. Skripsi. Fakultas pertanian Universitas Lampung. Bandar Lampung. $97 \mathrm{hlm}$.

Suryaningsih, C., Santoso, Y.S., dan Hardiatmi, J.M.S. 2018. Pengaruh macam limbah minuman dan komposisi media tanam terhadap pertumbuhan dan hasil tanaman sorgum (Sorghum bicolor L.). Jurnal Inovasi Pertanian 20(2) : $10 \mathrm{hlm}$.

Tabri, F. dan Zubachtirodin. 2016. Budi Daya Tanaman Sorgum. Balai Penelitian Tanaman Serealia. Jawa Timur. $13 \mathrm{hlm}$.

Tohari. 2007. Budidaya Tanaman Pangan Utama : Aspek Ekonomi dan Botani Tanaman Serealia. Universitas Terbuka. Jakarta. 41 hlm.

Yanuar, L.G.P. 2018. Penampilan agronomi dan hasil etanol beberapa genotipe sorgum (Sorghum bicolor (L.) Moench) pada lahan dengan penambahan unsur hara mikro. Skripsi. Fakultas Pertanian Universitas Lampung. Bandar Lampung. $76 \mathrm{hlm}$.

Yuliasari, R., Kamal, M., dan Sunyoto. 2014. Distribusi bahan kering sorgum (Sorghum bicolor (L.) Moench) yang ditumpangsarikan dengan ubikayu (Manihot esculenta Crantz). J. Agrotek Tropika 2(1) : 61-64. 
